\title{
EXPRESSIVE UTTERANCES AS FOUND IN ZACH SANG SHOW ON YOUTUBE
}

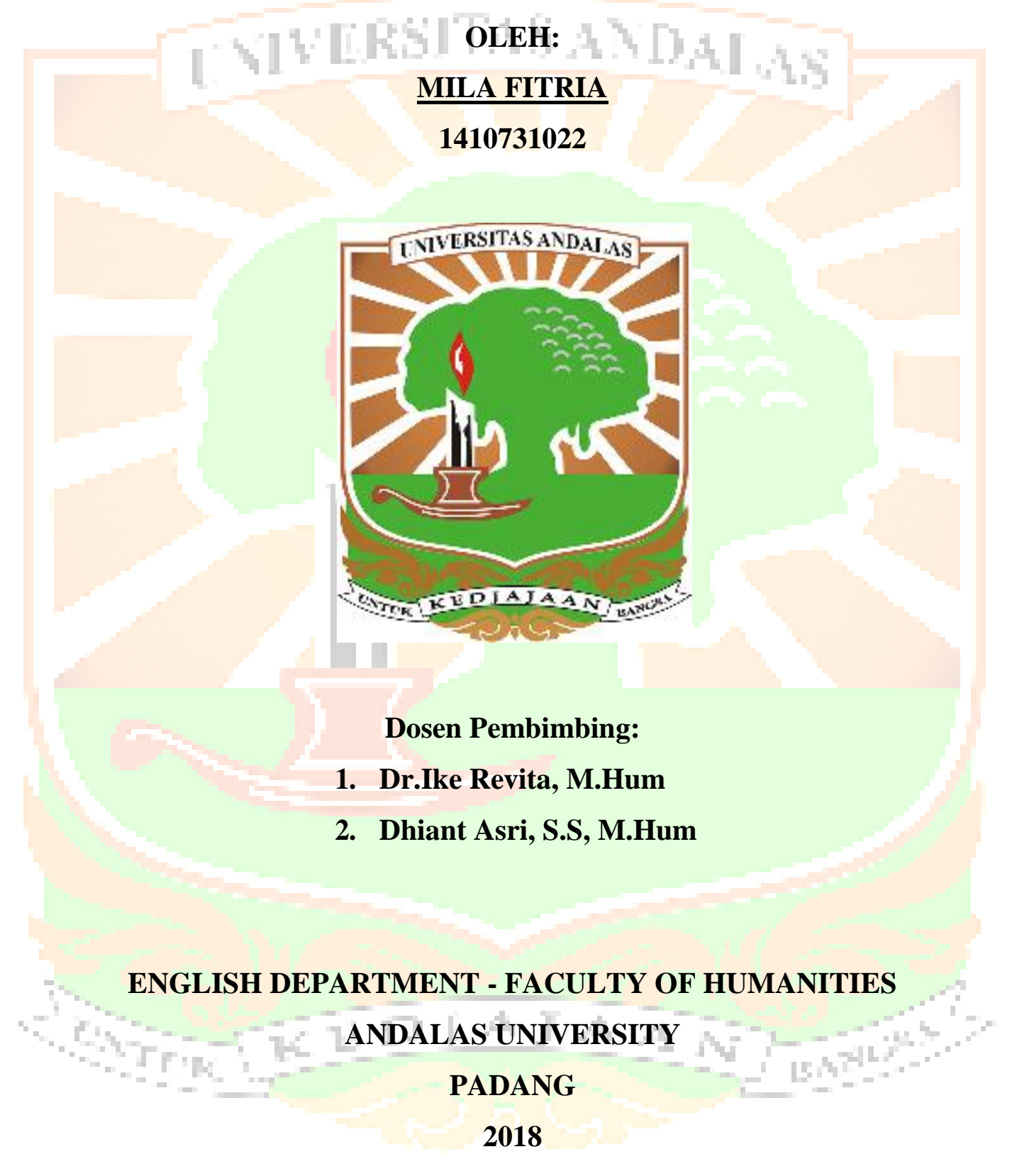




\begin{abstract}
ABSTRAK
Skripsi ini membahas tentang tuturan ekspresif yang ditemukan dalam video interview Zach Sang Show di YouTube.Video ini merupakan wawancara yang dilakukan oleh Zach Sang and the Gang pada Selena Gomez sebagai bintang tamunya.Tujuan penelitian ini adalah untuk menganalisis tipe-tipe tuturan ekspresif dan mengidentifikasi fungsi-fungsi dari tuturan ekspresif yang ditemukan dalam wawancara tersebut.

Data dikumpulkan dengan menggunakan metode observasi dan teknik catat. Data yang telah dikumpulkan selanjutnya dianalisis dengan menggunakan metode padan pragmatik. Teori yang digunakan dalam menganalisis data adalah teori tipetipe tuturan ekspresif yang dirumuskan oleh Ronan (2015) dan teori fungsi-fungsi dari tindak tutur ekspresif yang disampaikan oleh Searle dan Venderveken (1985). Data selanjutnya dipresentasikan dalam bentuk narasi dan tabel.

Tuturan ekspresif yang ditemukan dalam video interview adalah berjumlah 87 tuturan. Penulis menemukan 10 tipe tuturan ekspresif diantaranya persetujuan, kemauan, ketidaksetujuan, pujian, kebanggaan, mengungkapkan kesedihan, berterima kasih, sapaan, keluhan yang tidak diarahkan dalam seruan, dan meminta maaf. Tipe tuturan ekspresif yang paling dominan muncul adalah tipe persetujuan. Hal ini menunjukkan adanya persamaan persepsi antara pembicara dengan lawan bicaranya. Penulis menemukan 14 fungsi tuturan ekspresif diantaranyauntuk menyenangkan, berkeinginan, untuk menyetujui, untuk tidak menyetujui, untuk memuji, untuk membanggakan, untuk meratapi, untuk berterima kasih, untuk menyapa, untuk mengeluh, untuk memberi kejutan, untuk meminta maaf, mengucapkan selamat, untuk menyanjung. Fungsi tuturan ekspresif yang paling dominan adalah untuk menyenangkan. Hal ini menunjukkan adanya perasaan kepuasan, kesenangan dan kenyamanan terhadap sesuatu.
\end{abstract}

Kata kunci : tuturan ekspresif, tipe tuturan ekspresif, fungsi tuturan ekspresif, Zach Sang 